\title{
СИМВОЛИКА СИНЕГО ЦВЕТА В РОМАНЕ Ж.-М. Г. ЛЕ КЛЕЗИО «LE DÉSERT»
}

Статья посвящена исследованию употребления синего ивета (bleu) в романе «Пустыня» ("Désert») известного франиузского писателя Жан-Мари Г. Ле Клезио. Синий иявет в романе - превалирующий иявет - имеет как нейтральное (узуальное), так и символическое значение, изучение которого представляет особый интерес.

Ключевые слова: синий ивет, оттенки синего цвета, символика ивета, узуальное значение, символическое значение, изветоним.

The article is devoted to the study of the use of blue color in the novel "Desert" by the famous French writer Jean-Marie G. Le Clezio. The blue color in the novel - the prevailing color - has both a neutral (conventional) and symbolic meaning, the study of which is of particular interest.

Key words: blue color, shades of blue color, symbolism of color, usual meaning, symbolic meaning, color designation.

В романе «Пустыня» («Désert») французского писателя Жан-Мари Гюстава Ле Клезио (Нобелевская премия по литературе 2008 года) два сюжета - исторический и современный сплетены воедино. Полумифическое племя Синих воинов, кочующих по пустыне и воюющих с французами, которые возобновили военные действия на севере Африки в начале XX в.

«Мужчинь в синих шерстяных бурнусах - синие покрывала затеняли их лица. Женщины - лица и руки - под тёмно-синими покрывалами. Ветер пустьни дул не переставая, песок хлестал женщин в лищо, и они надвигали на глаза синие покрывала. Смуглая кожа их щёк, рук и ног отливала тёмносиним; на лбу переливались синие узоры татуировки. Синяя одежда превратилась в лохмотья». 
Цвет и его различные оттенки в романе имеют как нейтральное (узуальное), так и символическое значение. В основном преобладают два цвета: цвет жёлтый, охристый (песок, солнце) и цвет синий (небо, море, колодцы в пустыне).

Синий цвет в романе - превалирующий цвет - «... был использован чтобы выразить сильное душевное волнение и чувственность героев, ...а также связан с идеей добра и красоты» [Камалов 2011: 316]. Даже ночь в романе не чёрная, а «красивая велюровая тёмно-синяя» (Une belle nuit de velours bleu sombre).

Синий цвет несёт особую символическую нагрузку, чтобы отобразить характеры, эмоции и чувства героев.

Синий и голубой цвет во французском языке обозначается лексемой «bleu», которая восходит к древнему нижнефранкскому диалекту [Давидян 2009: 186]. Значит, одно и то же слово «bleu» используется как для синего цвета, так и для голубого. Голубой цвет можно передать bleu-clair, bleu ciel (небесно-голубой), bleuâtre (голубоватый).

Главная героиня романа - юная Лала Хава - потомок Синих людей, воителей Сахары. Из нищего городка на севере Марокко она едет на заработки в Марсель, и в этом чужом ей, враждебном краю нежданно-негаданно она становится знаменитостью, звездой модных иллюстрированных журналов, но без сожаления покидает Европу ради пустыни. Ей всегда помогал взгляд Синего человека - воина пустыни (Homme Bleu du désert), которого она себе представляла, и знала, что он ей помогает и даёт силы. Она назвала его «Es Ser» - (Secret «Секрет»), о котором никому не рассказывала. Нередко синий цвет выступает как символ неизвестного, секретного и таинственного.

Несмотря на всю его холодность, синий цвет ассоциируется с чистотой, глубиной, тайной. «Люди издавна наделяли цвета символическим значением. Во фразеологических единицах английского языка синий цвет может ассоциироваться с королевской властью и благородством происхождения (например, blue blood «аристократическое происхождение, голубая кровь») [Уразметова 2019: 234]. Такое же значение имеет прилагательное «bleu» в выражении «le sang bleu».

Главная героиня романа «Пустыня» Лала - из рода шерифов - князей, происходящих от самого пророка Магомета, предком её был святой чудотворец. И всё же главная причина 
необыкновенности Лалы не в родословной, а в том, что она осенена высшей таинственной силой - силой пустыни.

Синий цвет - это цвет Вселенной, космоса, галактики. Нередко синий цвет рассматривается как божественный. В мифологическом сознании небо всегда было обиталищем богов, духов предков, ангелов, отсюда главный символ синего божественность.

«Elle était la fille du sable,du vent, de la lumière, dela nuit, comme si elle était née du ciel sans nuages, elle avait la lumière de son regard, la liberté de l'espace dans son regard ...».

Автор использует синий цвет в романе, чтобы отобразить характер, эмоции и чувства главной героини. Ле Клезио посвящает отдельные большие главы описанию неба и моря. Лала любит бывать у моря, часами может наблюдать за полётами чаек над морем или смотреть на небо. Она всматривается в разные оттенки синего моря и не видит границы между небом и морем, так и небо и море синего цвета. Синий цвет (bleu) передаёт чистоту душевных помыслов, цвет самой души - это чистый цвет. «Синий наиболее часто рассматривается как символ всего духовного. Его считают самым глубоким и менее всего материальным цветом, медиумом правды, прозрачностью наступающей пустоты» [Приходько 2008: 55].

«Le ciel est bleu léger, transparent, paraît plus propre, plus bleu et lisse au-dessus de la terre blanche».

«elle pense à la mer si bleu»

«elle a vu la mer très bleu»

«elle entend la musique céleste»

«ll y a de grands lacs d'eau bleue comme le ciel».

В романе Ле Клезио «Désert» все слова, обозначающие цвет синий, несут позитивный смысл, чётко передают авторское отношение к героям. Прилагательное «bleu», обозначающее синий цвет, помимо указания на определённую шкалу цветового спектра, употребляется для того, чтобы передать сильные эмоции и чувства главной героини и лучше понять её характер.

Лексическая система любого языка является динамичной и открытой к любым изменениям, которые происходят под влиянием экстра и интралингвистических факторов [Рябцова 2020:88]. Использование цветовых терминов значительно повышает эмоционально-экспрессивный

смысл 
коммуникативного процесса; эти языковые единицы могут выражать самые тонкие отношения и аспекты жизни людей. Слова-цветообозначения (цветонимы), отражают процессы цветовых ощущений в языке и обладают большим эмоциональноэкспрессивным воздействием.

1. Давидян 3.О. Семантика цветообозначения bleu/azul во французском и испанском языках (универсальное и национальное) / 3.О. Давидян // Вестник Волгоградского государственного университета. Серия: Языкознание. - 2009. №1. С. 185-188.

2. Камалов Р.И. Проблемы перевода символики цвета в романе Готорна «Алая буква» // Актуальные проблемы современной лингвистики глазами молодых учёных: материалы регионального научного семинара. - Уфа: РИЦ БашГУ, 2011. C. 316.

3. Рябцова Н.И. Способы решения омонимического конфликта во французском языке // Языковые единицы в свете современных научных парадигм: материалы $\mathrm{V}$ Всероссийской научно-практической конференции с международным участием (г. Уфа, 18 декабря 2020 г.). - Уфа: РИЦ БашГУ, 2020. С. 88-92.

4. Приходько В.К. Выразительные средства языка: учеб. пособие для студ. высш. учеб. Заведений / В.К. Приходько. М.: Издательский центр «Академия», 2008. - 256 с.

5. Уразметова А.В. «Синие» топонимы на карте США // Коммуникативные единицы в свете современных научных парадигм: сборник материалов Всероссийской научнопрактической конференции с международным участием, посвященной 80-летию со дня рождения доктора филологических наук, профессора, Заслуженного деятеля науки Республики Башкортостан, Почетного работника высшего профессионального образования Российской Федерации Кильдибековой Танзили Асхатовны (г. Уфа, 26 ноября 2019 г.). - Уфа: РИЦ БашГУ, 2019. Т. І. - С. 230-234.

СРябцова Н.И., 2021 г. 